\title{
GEOHERITAGE CONSERVATION IN ETHIOPIA: THE CASE OF THE SIMIEN MOUNTAINS
}

\author{
Asfawossen Asrat \\ Department of Earth Sciences, Addis Ababa University, Addis Ababa, Ethiopia \\ Metasebia Demissie \\ Geo-Information and Landscape Gardening, Addis Ababa, Ethiopia \\ Aberra Mogessie \\ Institute of Earth Sciences, University of Graz, A-8010 Graz, Austria
}

Manuscript received: February 17, 2012

Revised version: March 3, 2012

\begin{abstract}
Asrat, A., Demissie, M. \& Mogessie, A., Geoheritage conservation in Ethiopia: the case of the Simien Mountains. Quaestiones Geographicae 31(1), Bogucki Wydawnictwo Naukowe, Poznań 2012, pp. 7-23. 15 Figs. DOI 10.2478/ v10117-012-0001-0, ISSN 0137-477X.

ABSTRACT. Ethiopia constitutes one of the most significant environmental and cultural reserves on Earth. Ethiopia's natural and cultural tourist attractions are mostly associated with geological features: the active Ethiopian and Afar rifts as well as the Simien and Bale massifs are few examples. Ethiopia's cultural history, religious manifestations and civilization, like the rock-hewn churches of Lalibela and the stelae of Axum, are also imprinted in rock. Geomorphological and geological features, notably the isolation of the north-western highlands from the external world by the harsh Afar depression close to the sea, determined the route of Ethiopian history. Though tourism has been identified as a major sustainable development sector, systematic geoheritage evaluation and conservation strategies are lacking in the country. In this paper the Simien Mountains are presented as major geoheritages which should be prioritized for geoconservation in order to develop sustainable tourism (geotourism) in the area.
\end{abstract}

KEY WORDS: geoheritage, geotourism, geoconservation, sustainable development, Simien Mountains, Ethiopia Asfawossen Asrat, Department of Earth Sciences, Addis Ababa University, P.O. Box 1176, Addis Ababa, Ethiopia, e-mail: asrata@geol.aau.edu.et

\section{Introduction}

Geological sceneries are defined as those large-scale geological and geomorphological features defining the natural physical scenery of a site, for example volcanic edificies. In this paper, we present selected geological heritages in Ethiopia in order to make a case for the fact that most of the cultural and natural touristic sites in the country are in fact, in one way or another, re- 
lated to geological processes and can be defined as geoheritages.

Geoheritage and geoconservation as well as the related terms geodiversity and geoparks are recently conceived and developed concepts and terms (Doyle et al. 1994; Semeniuk \& Semeniuk, 2001; Brocx \& Semeniuk 2007; Brocx 2008). As a result, these terms are loosely applied to various concepts in various geological literatures. In this paper, we used the terms geoheritage and geoconservation in the sense of their application as proposed by Brocx (2008). Accordingly geoheritage refers to globally, nationally, state wide, to local features of geology, such as its igneous, metamorphic, sedimentary, stratigraphic, structural, geochemical, mineralogical, paleontological, geomorphic, pedological, and hydrological attributes, at all scales, that are intrinsically important sites, or culturally important sites, that offer information or insights into the formation or evolution of the Earth, or into the history of science, or that can be used for research, teaching, or reference (Brocx 2008); while geoconservation refers to preserving sites of geoheritage significance (Semeniuk \& Semeniuk 2001). Geodiversity on the other hand is defined as the natural variety of geological, geomorphological, pedological, hydrological features of a given area, from the purely static features ... at one extreme, to the assemblage of products, and at the other, their formative processes ... (Semenuik 1997; Brocx 2008). A geopark as conceptualized by UNESCO (United Nations Educational, Scientific and Cultural Organization) refers to a territory with welldefined limits that has large enough surface area for it to serve local economic development. The geopark comprises a number of geological heritage sites of special scientific importance, rarity or beauty; it may not be of solely of geological significance but also of archaeological, ecological, historical or cultural value (Brocx 2008). The objectives of establishing a geopark are to use the geological sites designed as geoparks in educating the broader public, and teaching in geological sciences and environmental matters; to contribute for sustainable development through geotourism; and to conserve geological heritage for future generations.

In the current world where economic developments in many parts of the world are mostly driv- en by large scale exploration and exploitation of earth resource sustainable development could be at risk without concerted effort of all concerned to preserve geological heritages. As a result, only recently have geoheritages been given due attention and geoconservation initiatives being recognized by many international institutions as of global importance (Brocx 2008). It is now largely recognized that earth systems are linked to the on-going history of human development, providing the resources for development, and a sense of place, with aesthetic, historical, cultural and religious values. The fact that geoheritages represent both discovered and yet undiscovered information about earth's history call for their protection, because if not conserved, they will be lost to future generations.

In this paper a brief summary of the geological and geomorphological setup of Ethiopia followed by a case study of the Simien Mountains as a geoheritage site is presented. Descriptions are based on field investigations, which included detailed scientific and photographic documentation, and an inventory-based classification of the geological features based on the existing geological diversity and unique features. Our aim is to clearly define and promote this place in particular and other sites described in Asrat et al. (2009) as geoheritage sites. The overall objective in this case and in all our previous studies is to give a scientific basis for policy makers to define the necessary legislation, policy and regulations for selecting and prioritizing among the most important geoheritages and geosceneries in the country for geoconservation programs and for the establishment of geoparks, in some of the geoheritage sites.

\section{Geoheritages and geoheritage research in Ethiopia}

Ethiopia hosts numerous geoheritages and geotourisitc sites, some of which have been granted UNESCO World Heritage status, though defined as cultural and/or natural heritage sites when registered (Fig. 1). These include the stelae of Axum (granted World Heritage status in 1980); the rock - hewn churches of Lalibela (1978); the Semien Mountains National Park (1978); the Fasiledes Castle in Gondar (1979); the prehistoric 


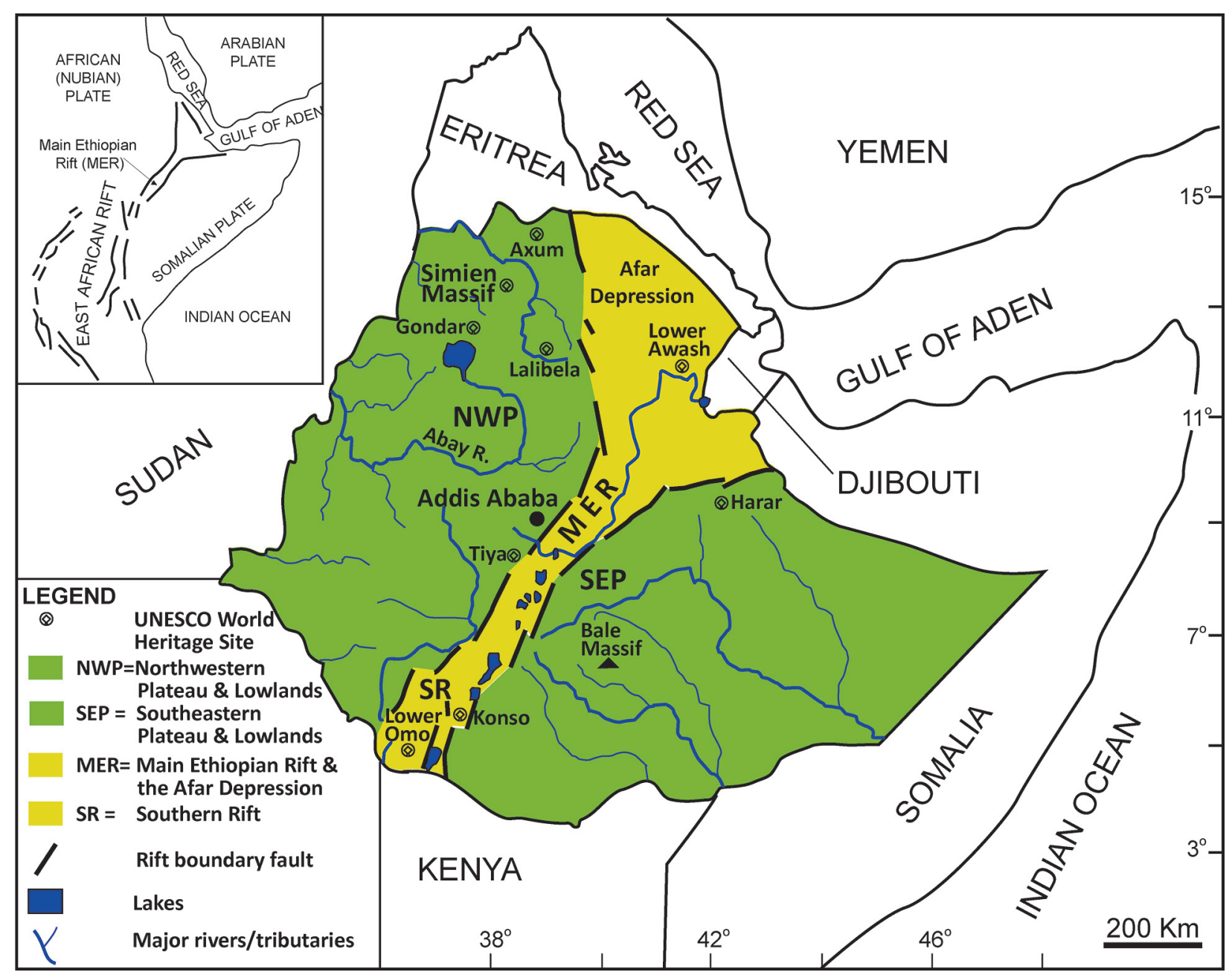

Fig. 1. Location Map of the World Heritage Sites in Ethiopia, and other localities and geographic features mentioned in the text. The inset shows the Great East African Rift System.

sites of Tiya (1980); the lower Valley of the Awash River (1980); the lower Valley of the Omo (1980); the Muslim Holy city of Harar (2006); and the Konso Landscape (2011).

In fact, Ethiopia constitutes one of the most significant environmental and cultural reserves on Earth, strewn with unique and significant geological and archaeological monuments. The underlying geological feature often determines natural scenery and landforms, and defines many tourist attractions all over the world. Ethiopia's most tourist attractions are good examples of this fact: the active Ethiopian Rift with its chain of rift lakes and the world-famous archaeological and anthropological sites; the unique Afar rift with its active volcanoes like Erta'ale and its expanding extension centre leading to the formation of new oceanic crust; the Simien and Bale massifs, the Tis-Isat fall along the mighty Blue Nile river, and the Sof-Omar caves are few examples. Ethiopia is also one of the few places in the world where its cultural history, religious manifestations and civilization are imprinted in rocks: the rock-hewn churches of Lalibela and Central and Eastern Tigrai, and the stelae of Axum are all there because of the unique geological materials available. Furthermore, geomorphological and geological features, notably the isolation of the north-western highlands from the external world by the harsh Afar depression close to the sea, determined the route of Ethiopian history.

However, systematic geoheritage evaluation and conservation strategies are lacking in the country, although tourism has been identified as a major sustainable development sector. We started addressing this issue by identifying the major geological heritage sites in the country and designed a project to make basic inventory and 
description of these geoheritages and geosites. The results of our first phase research have been published in a book entitled Geotourism in Ethiopia (Asrat et al. 2009). The second phase of the project presents geological and geomorphological sites and sceneries, among which the case of the Simien Mountains is presented in this paper.

\section{Geological Setting of Ethiopia}

Ethiopia underlies an immense succession of rocks representing a long geologic history starting from the Precambrian. These successions are sculpted by continuous geomorphological and tectonic activities, which are still active, resulting in a wide range of landforms: from high mountain ranges, through wide plains with deep ravines and gorges and undulating plains, a wide rift valley to salt plains below sea level. Ethiopia could be marked as an ideal text book of geology and geomorphology (Asrat et al. 2009; Fig. 2). The geologic history of Ethiopia can be sub-divided into four major geologic eras: the Precambrian, Palaeozoic, Mesozoic, and Cenozoic.

The oldest (about $1.1 \mathrm{Ga}-500 \mathrm{Ma}$ ) rocks in Ethiopia are Precambrian metamorphic rocks formed by repeated orogenic processes (e.g., Asrat et al. 2001). Two major Precambrian structures of Northeast Africa and Arabia meet in Ethiopia: The Arabian-Nubian Shield (ANS) and the Mozambique Belt (MB) were built simultaneously within the Pan African Orogeny (950-500 Ma) (Asrat et al. 2001). The ANS sector (a volcanosedimentary accretionary terrane dominantly exposed in northern and north-western Ethiopia and Eritrea) is a juvenile domain formed by subduction related accretion, while the MB (a gneissic-migmatitic terrane dominantly exposed in southern and south-western Ethiopia) involves continental collision and some recycling of an older crust during the Pan-African (Asrat et al. 2001; 2003).The Precambrian rocks comprise low-grade metavolcano-sediments and medium to high-grade schists and gneisses, and associated granitic and mafic/ultramafic intrusions. The Basement complex is exposed in the peripheral parts of the country representing nearly a quarter of the surface area (Fig. 2).
The Palaeozoic era (543-251 Ma) in Ethiopia was characterized by extensive erosional processes, which reduced the mountains formed by the crystalline basement into a peneplain. As a result, very few deposits were formed during this era. The peneplanation of the crystalline basement during the Upper Palaeozoic was followed by some continental fluviatile deposition of calcareous sandstones, glaciations and deposition of glacial tillites (Bosellini et al. 1997; Asrat 2002). Upper Palaeozoic rocks are exposed in some parts of northern, central and eastern Ethiopia on low hills dissected by deep canyons, and in some cases forming prominent buttes and mesas (Fig. 2).

Alternate sinking and uplifting of the landmass of the whole horn of Africa triggering transgression of the Indian ocean from the southeast to the northwest during the Early Mesozoic (depositing the fluviatile, mature, up to $700 \mathrm{~m}$ thick, cliff forming Adigrat sandstone), deepening of the ocean during the Middle Mesozoic (depositing the near shore, sub-continental and marine Antalo limestone and shale successions), and regression of the sea from the northwest to the southeast back to the Indian ocean during the Late Mesozoic (depositing the immature, clastic Ambaradam sandstone) characterized the Mesozoic era (251-65 Ma) in Ethiopia (Bosellini et al. 1997; Asrat 2002). The Mesozoic and Palaeozoic sedimentary rocks, exposed mostly in northern, central and eastern Ethiopia, comprise a quarter of the surface area of the country (Fig. 2).

The geologic processes that occurred during the Cenozoic era (65 Ma-Present) contributed most to the present landform of Ethiopia. The Cenozoic era witnessed:

- the uplifting of the Ethio-Arabian landmass, followed by deep seated crustal fracturing and subsequent outpouring of huge quantity of basaltic and associated lava now forming the North-western and South-eastern Plateaus (the Trap Series) of Ethiopia during the Oligocene (over a short time period of 1-2 Ma centred at about $30 \mathrm{Ma}$ ago; Hofmann et al. 1997);

- breaking up of the uplifted dome and formation of the Rift valley during the Middle Cenozoic, as well as eruptions of lava and pyroclastic materials through centralized vents form 


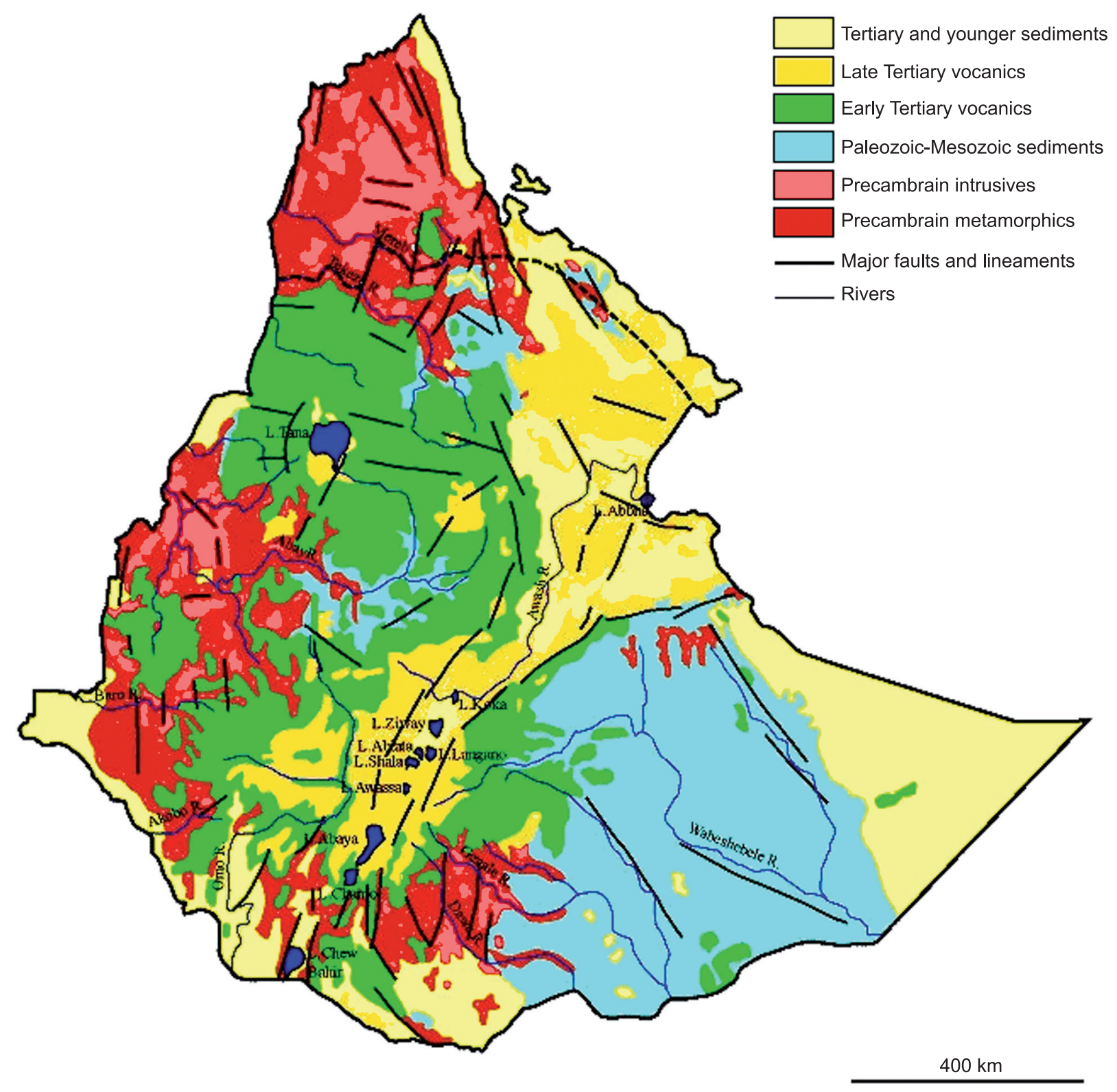

Fig. 2. Simplified geological map of Ethiopia and Eritrea (after Asrat et al. 2009).

huge central and shield volcanoes, over the Trap Series, during Middle to late Miocene;

- recent volcanism and sedimentation during the Late Cenozoic (Quaternary).

The trap series topped by the central and shield volcanoes were later eroded and sculpted to form the spectacular chains and peaks as well as adjoining ravines and gorges of the Simien and Bale mountains.

The Ethiopian Rift system extends from the northeast end at the Afar depression, through the Main Ethiopian Rift System at the centre, to the Southern Rift at the south-western end. During Oligocene-Miocene, the up-arched EthioArabian swell was fractured along parallel major faults resulting in the formation of a structural depression, the Rift valley, as a result of NW-SE oriented extensional tectonic forces. The rifting and faulting along with volcanic eruptions continued throughout the Miocene to the Quaternary shaping and reshaping the Rift valley. The Afar Depression is currently a place of intense tectonic and active volcanic processes where continental break up is being witnessed (Wright et 
al. 2006). In the Main Ethiopian Rift, Quaternary active volcanism and volcano-tectonic phenomena are restricted to its axial zones (Mohr 1962; Di Paola 1972). Basalts, trachytes, rhyolites, ignimbrites, tuff and associated pyroclastic deposits constitute the Tertiary and Quaternary volcanic. They cover nearly half of the surface area of the country. Late Miocene - Pliocene fluvio-lacustrine sediments are exposed in many localities in southern Afar and the northern sector of the Main Ethiopian Rift, as well as the Lower Omo Valley in the Southern Rift. These sediments have been the subject of extensive palaeoanthropologicalarchaeological research and returned numerous hominid as well as other faunal fossils and archaeological materials. During the Quaternary, sedimentation occurred associated to lacustrine and marine environments, mainly exposed in the Lakes region of the Ethiopian Rift System and the Afar depression, covering about $11 \%$ of the surface area of the country (Fig. 2).

\section{Geomorphological setting of Ethiopia}

Diverse geomorphological features characterize the Ethiopian landform. It ranges from flattopped plateaus, high and rugged mountains, deep river gorges, rolling plains, long sub-vertical to vertical escarpments, structural depressions and elevated blocks to salt plains below sea level. Altitude ranges from over $4600 \mathrm{~m}$ above sea level to more than $100 \mathrm{~m}$ below sea level. Although the highest peak in Ethiopia (Ras Dashen: 4,620 m a.s.l.) is only about $1,200 \mathrm{~m}$ below the highest peak in Africa, the largest proportion of most elevated landmass in Africa is located within the territories of Ethiopia, hence the most-cited reference of Ethiopia in this regard as the Roof of Africa. However, the contrast in elevation is so tantalizing that the lowest continental surface in Africa (about $120 \mathrm{~m}$ below sea level) is also located in Ethiopia in the Afar Depression. Three major geomorphic regions characterize Ethiopia: the North-western Plateau and lowlands the South-eastern Plateau (SEP) and lowlands, and the Ethiopian Rift System (MER) (Figs. 1-3).

The Cenozoic volcanic and tectonic episodes especially determined the current landform of
Ethiopia. The uplifting and subsequent outpouring of huge quantities of lava during Oligocene spread either on a peneplained Precambrian surface or over the thick Mesozoic sedimentary successions, forming an outward sloping plateau, towered, in places, by Miocene shield volcanoes. Major and extensive faulting along crustal-scale fractures resulted in the formation of two asymmetrical plateaus (Fig. 3).

The North-western Ethiopian Plateau (NW highlands) is a broad, mainly flat-topped mass, in places topped by enormous shield volcanoes. This massif was subsequently dissected by deep erosional gorges formed by the major west or south-westward draining river basins of the Blue Nile, Tekeze, Omo and their tributaries. The north-western highlands are bordered to the east by prominent, generally N-S trending, stepped, faults and fault blocks forming the escarpment. The escarpment zone is characterized by a series of long, narrow grabens, which first formed during early normal faulting along the western margin of the Afar Depression (Beyene \& Abdelsalam 2005). The North-western highlands cede in the west and southwest to the western lowlands of Ethiopia (Figs. 1-3).

The South-eastern Ethiopia Plateau (the Somalian Plateau) is a narrow, prominent volcanic landmass rising to more than 3,000 $\mathrm{m}$ a.s.l., and reaching to about $4,200 \mathrm{~m}$ a.s.l., comprising the high rising mountain chains of the Arsi-Bale Masifs (Figs. 1-3). This massif was subsequently dissected by deep erosional gorges formed by the major east- and south-eastward draining river basins of Wabe Shebelle, Genale, and Dawa. The highlands cede in the east to the Somalian lowlands. Prominent stepped tectonic escarpments bound this highland mass from the west.

The Ethiopian Rift System (Figs. 1-3) is the northernmost part of the East African Rift System. The Ethiopian Rift system is bounded by vertical to sub-vertical series of rift margin escarpments from the west and the east. These escarpments are major NNE-SSW oriented fault scarps formed by the downward movement of the present-day rift floor from the highlands during the inception of the rift, subsequent to the major uplifting and fracturing of the Ethio-Arabian landmass. The eastern escarpment is usually more strongly developed than the western escarpment. The 


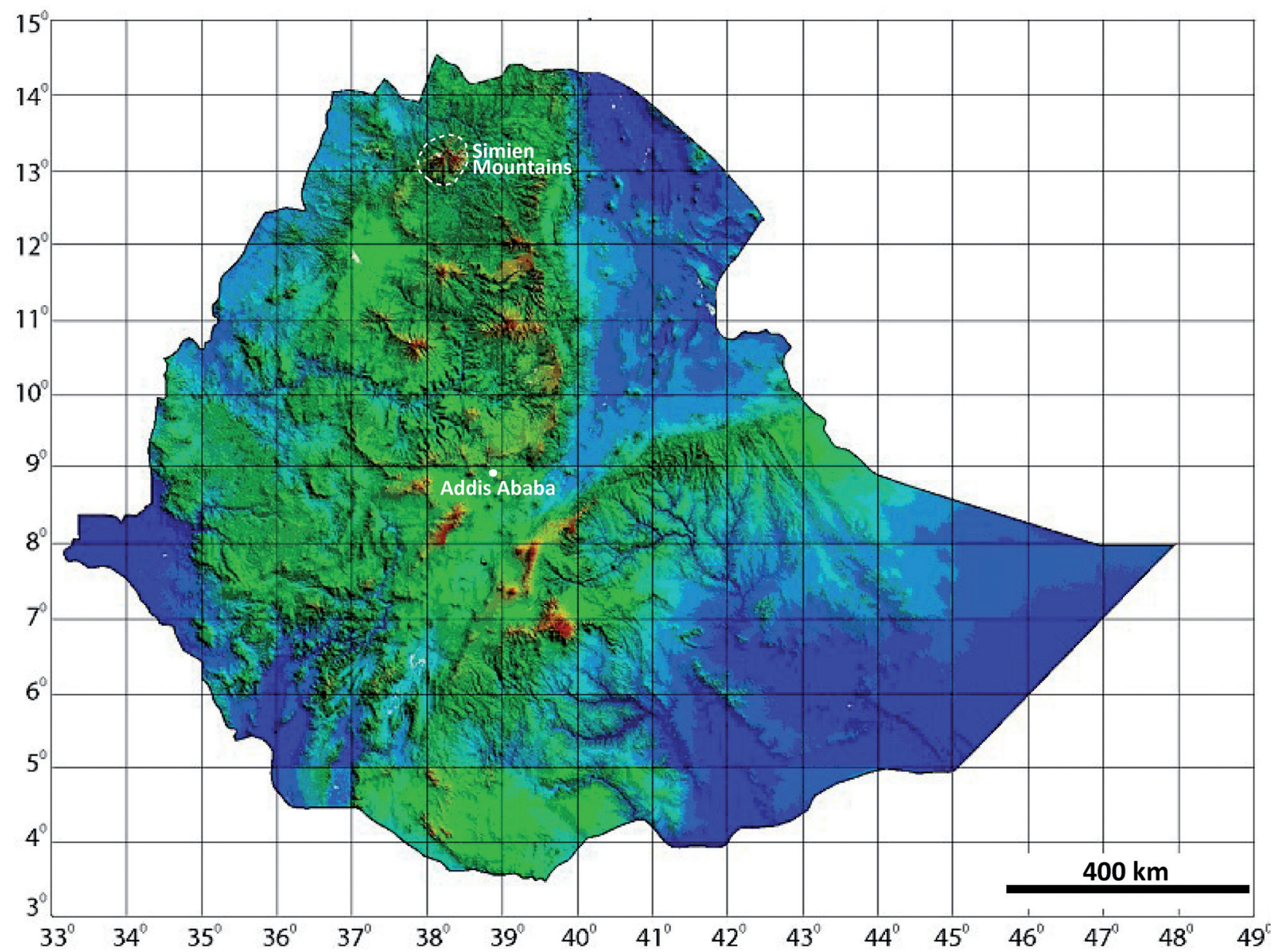

Fig. 3. Digital Elevation Map (DEM) of Ethiopia indicating the plateaus dissected by the Rift Valley. The elevations range from about $120 \mathrm{~m}$ below sea level to more than 4,600 $\mathrm{m}$ a.s.l. (Deep blue colour represents elevations below $500 \mathrm{~m}$ a.s.l.; blue: 500-750 m; light blue: 750-1,000 m; light green: 1,000-1,500 m; deep green: 1,500-2,500 m; yellowish shade: 2,500-3,500 m; and red: above 3,000 m elevation).

Ethiopian Rift System is divided, from northeast to southwest, into the Afar depression, the Main Ethiopian Rift, and the Southern Rift (SR).

The Afar Depression is extensive, tectonically and volcanically active lowland located in Northeastern Ethiopia, located at the junction of three actively propagating rift zones:

a) the southern Red Sea rift which is extending from north down into the northern Afar Depression;

b) the Gulf of Aden rift which is propagating through Djibouti into the eastern Afar Depression; and

c) the Main Ethiopian Rift which is extending to the southwest.

The overall structural evolution of the Afar depression occurred in three stages (Wolfenden et al. 2005): a) formation of long, vertical to sub-vertical border faults during the Oligo-Miocene;

b) eastward migration of active faulting and magmatism to narrow zones within the centre of wider rift systems, during Mid Miocene; and

c) finally development of sea-floor spreading style magmatic segments within the centre of the rift zones with strain accommodated by dyke injection.

The Main Ethiopian Rift (MER) extends from the Lower Awash valley in the northeast, where it opens to the Afar depression, to the southern shore of Lake Chamo in the southwest. With an average width of about $70 \mathrm{~km}$, it is the narrowest part of the Ethiopian rift system (e.g., Beyene \& Abdelsalam 2005). It is bordered by discontinuous series of large, vertical to sub-vertical Miocene aged normal faults (Pizzi et al. 2006). The 
main rift is dotted with a series of Quaternary rift basins where current rift extension and both basaltic and silicic magmatism is focused (Hayward \& Ebinger 1996). Since the Middle Pleistocene fluvio-lacustrine basins developed along the Quaternary Rift Basins under a tectonic-volcanic control (Le Turdu et al. 1999), followed by development of the Late Pleistocene-Holocene fluvio-lacustrine basin of the Lakes region.

The Main Ethiopian rift splits into two branches south of the Lake Abaya-Chamo basin. The eastern branch forms the southernmost sector of the Main Ethiopian Rift. In the western sector, rift faulting dies out at the southern shore of Lake Chamo but resumes further west in the Chew Bahir basin (Figs. 2 \& 3). This basin lies in a $300 \mathrm{~km}$ wide rift zone, between the Omo-Turkana Basin to the west and the southern sector of the Main Ethiopian Rift to the east. This basin is bounded to the west by uplifted Precambrian crystalline metamorphic rocks, and to the east by a ridge composed of Miocene basalts.

\section{The Simien Mountains}

\subsection{Background}

The Simien Mountains form a prominent and spectacular landscape in North-western Ethiopia offering grand scenery over the rugged-canyon like lowlands. The Simien Massif, one of the major highlands of Africa, forms a spectacular erosive landscape characterized by deep valleys, jagged mountains and sharp droppings and precipices of more than 1,500 $\mathrm{m}$ (Fig. 4). Some territories of the Simien Mountains were included in the Simien Mountains National Park which was established in 1969. The park was inscribed in 1978 as one of the four UNESCO world heritage sites from Ethiopia. The park is located in the western Simen Mountains, $120 \mathrm{~km}$ northeast of Gondar town centered at $13^{\circ} 11^{\prime} \mathrm{N}, 38^{\circ} 04^{\prime} \mathrm{E}$, and the town of Zarema lies to the north, Debark, 50 $\mathrm{km}$ to the southwest and Tekeze River basin to the east. A road that extends from Debark is the main accesses to the park (Fig. 5). The park extends in an area of 22,000 ha and lies within an altitudinal range of 1,900 to $4,430 \mathrm{~m}$ a.s.l. (WHC, 2010). The Park lies on the spectacularly rugged and dissected northern edge of the vast undulating Geech plateau in the western part of the Simien volcanic massif which has been continuously eroded since its formation resulting in precipitous cliffs and deep gorges of exceptional natural beauty. The Park occupies a narrow strip extending east-northeast for $35 \mathrm{~km}$ on top of a 1,500 m high escarpment. The plateau is dissected north to south by fast-flowing permanent streams and high waterfalls draining to the northeast and south to deep valleys tributary to the Tekeze River. The lowest reaches of the Simien massif to the north are outside the park, while the highest points of the Simien massif including the highest point in the country, the Ras Dashen at an altitude of 4,624 $\mathrm{m}$ a.s.l. overlook the park from the south.

The Simien Mountains are of global significance for biodiversity conservation because it is home to globally threatened species, including the iconic Walia Ibex (Capra walie), the Gelada baboon (Theropithecus gelada), and the Ethiopian wolf (Canis simensis) (WHC, 2010). The World Heritage Committee placed the Park area on the List of World Heritage in Danger in 1996 because of decline in the population of the Walia ibex due to human settlement, grazing, agriculture and road construction (WHC, 2010). The Park, starting from its time of establishment enclosed several villages, and was about $30 \%$ cultivated land. Naturally fertile volcanic soils are currently degraded because of overgrazing and over cultivation.

The Simien Massif is located in one of the wettest and coldest regions of the country with a mean annual rainfall of $1,550 \mathrm{~mm}$ falling in two rain seasons, from February to March, and July to September, and temperatures ranging from a minimum of $-2.5^{\circ} \mathrm{C}$ to $4^{\circ} \mathrm{C}$ to a maximum of $11^{\circ} \mathrm{C}$ to $18^{\circ} \mathrm{C}$. Dry, windy days and frosty nights are common, while snow occasionally settles on the Ras Dashen and other summits above 4,200 $m$ elevation. As a result of their great altitudinal, topographic and climatic diversity, the Simien Mountains are rich in biodiversity within their Afromontane and Afroalpine ecosystems. The mountains are part of the Afro-alpine Centre of Plant Diversity, and form part of the Eastern Afromontane biodiversity hotspot with numerous endemic plant and animal species. The veg- 
etation grows in four belts related to altitude: Afromontane forest, Hypericum woodland, Afromontane grassland and Afro-alpine moorland (Hurni 1986, 1995). The Simien Mountains are home to 21 mammal species amongst which seven are endemic, though currently most are endangered due to habitat alteration caused by human impacts (agriculture, animal grazing, etc.). The main habitat of the Endangered Walia ibex, a wild mountain goat endemic to the Simien Mountains and numbered at about 600 individuals (Debonnet et al. 2006) is the cliff areas of the northern escarpment of the mountains in and outside the park. Other species include the endangered Ethiopian wolf (or Simien fox), considered to be the rarest canid species in the world and the Gelada baboon, both of which are endemic to the Ethiopian highlands and depend on Afroalpine grasslands and heathlands. Other large mammal species include the Anubis baboon, Hamadryas baboon, klipspringer, and golden jackal (WHC, 2010). The Simien Mountains are also an Important Bird Area that forms part of the larger Endemic Bird Area of the Central Ethiopian High- lands, with 137 recorded bird species including 16 endemic to Ethiopia (Fishpool \& Evans 2001).

\subsection{Geological and geomorphological Setting}

The Simien Mountains are traditionally acclaimed and globally recognized for their biodiversity. However, the Simien Mountains should equally be recognized for their geodiversity. The Simien Mountains represent a major OligoMiocene volcanic shield built over the Oligocene flood basalts, which altogether form the Northwestern Ethiopian highlands (Fig. 4).

The Ethiopian flood basalts (the traps), which mostly erupted around $30 \mathrm{Ma}$ ago during a short 1 Ma period (Hofmann et al. 1997), form a vast volcanic plateau, later partly covered by large shield volcanoes (Mohr 1983; Mohr \& Zanettin 1988; Hofmann et al. 1997; Pik et al. 1998; 1999; Kieffer et al. 2004). The Trap sequence forming a variable thickness reaching up to $2 \mathrm{~km}$ in some areas covers about $55 \%(\sim 600,000$ sq. $\mathrm{km})$ of the

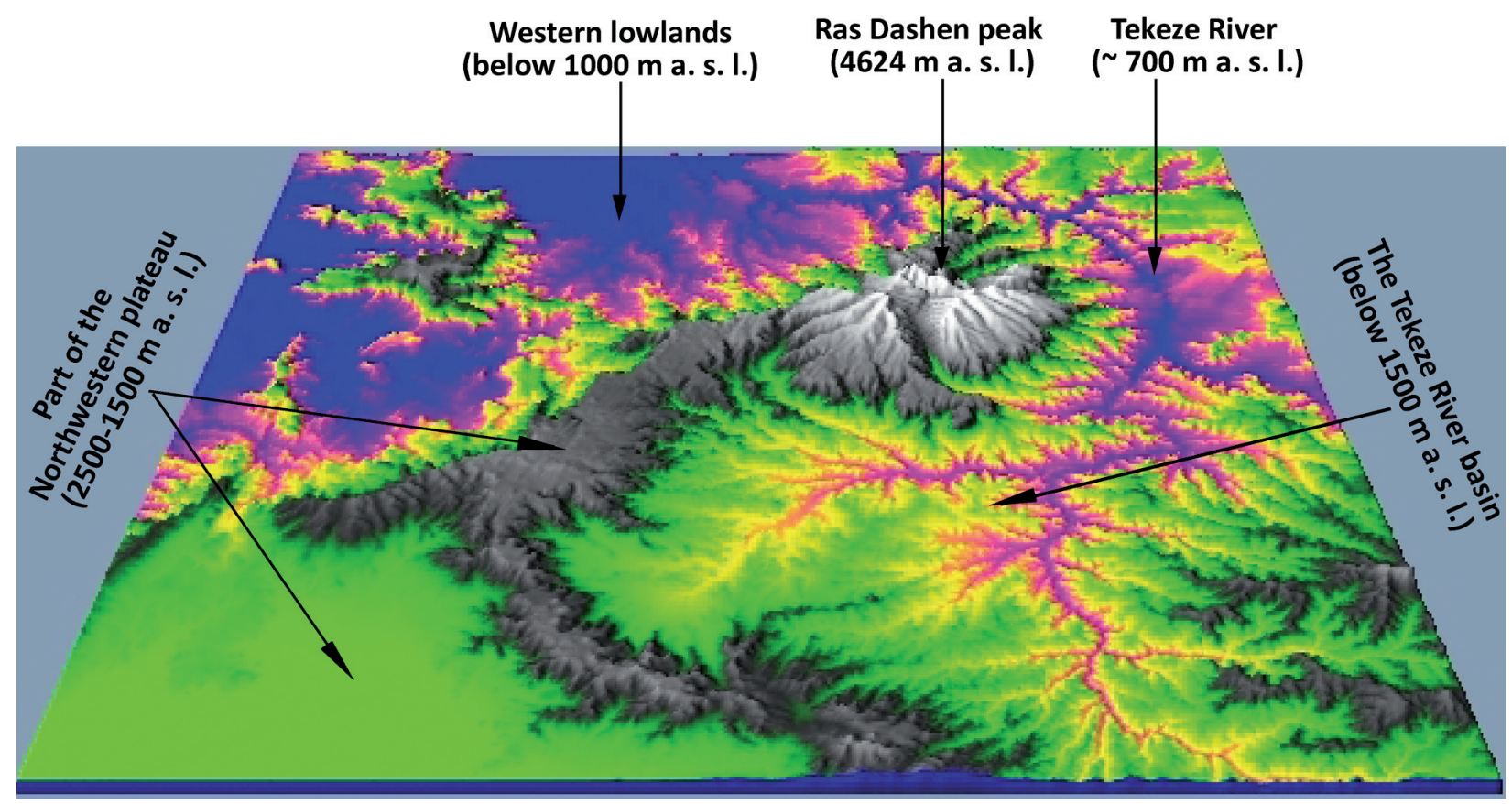

Fig. 4. Digital Elevation Model (constructed using 90 m SRTM images) of the Northwestern Ethiopian highlands highlighting the Simien Shield (grey and whitish coloured nearly circular volcano towards the top right corner of the DEM). The basal diameter of this shield is about $100 \mathrm{~km}$. The Tekeze river rounds the shield from the east to the north and west. The dark grey and bright greenish colour represents the trap sequence (partly eroded) between the elevations 2,500-1,500 $\mathrm{m}$ a.s.l. The bright purple and blue colours represent the river gorges and western lowlands $(1,500-1,000 \mathrm{~m}$ a.s.l., and below $1,000 \mathrm{~m}$ a.s.l., respectively). 
surface area of the country. They form thick and continuous lava flows composed of relatively uniform, tholeiitic to transitional basalts and subordinate felsic rocks. The basalts are mostly aphyric to sparsely phyric with phenocrststs of plagioclase and clinopyroxene and rarely olivine. The felsic lava flows and tuffs/ignimbrites, which are common towards the top of the sequence, are mostly rhyolitic and rarely trachytic (Ayalew et al. 1999). The shield volcanoes form prominent landscape in the north-western Ethiopian highlands with basal diameters ranging from 50-100 $\mathrm{km}$ and maximum original height (taking into account the eroded material) reaching to $3 \mathrm{~km}$ at the highest peaks of the Simien shield, raising above the flood basalt plateau (e.g., Mohr, 1967; Kieffer et al., 2004). The shield volcanic edifices were built at 31-30 Ma ago for the Simien shield, $23 \mathrm{Ma}$ ago, and $11 \mathrm{Ma}$ ago for other shields to the south. The shields in general have similar composition with the respective underlying flood basalts, possibly suggesting similar magmatic sources and processes, though individual lava flows of the former are thinner and less continuous, and are more porphyritic in texture. The tholeiitic Simien shield, for instance was built over tholeiitic flood basalts (Kieffer et al. 2004).

In the Simien Mountains, almost a complete sequence of generally horizontal flood basalt flows, and the lower parts of the shield volcanic sequence are exposed at the Lima Limo escarpment along the Zarema-Debark road (Fig. 5). The flood basalts form gentler slopes at the bottom and prominent vertical cliffs at the top forming the characteristic gigantic plug and spire-like morphology of the Simien Mountains region. The Lower Flood Basalt formation (Pik et al. 1998; Kieffer et al. 2004) is exposed between 1,200 $\mathrm{m}$ and $\sim 1,800 \mathrm{~m}$ altitude and is comprised of $10-15 \mathrm{~m}$ thick, aphyric or sparsely phyric, massive basaltic flows at the bottom and sparsely to highly porpyritic, 10-15 m thick, massive basalt flows at the top, with no felsic rocks. The Upper Flood basalt formation is exposed between $\sim 1,800$ and $\sim 2,700$ $\mathrm{m}$ altitudes. It consists of highly Plag-porphyritic, $10-15 \mathrm{~m}$ thick, massive basalt flows and $30 \mathrm{~m}$

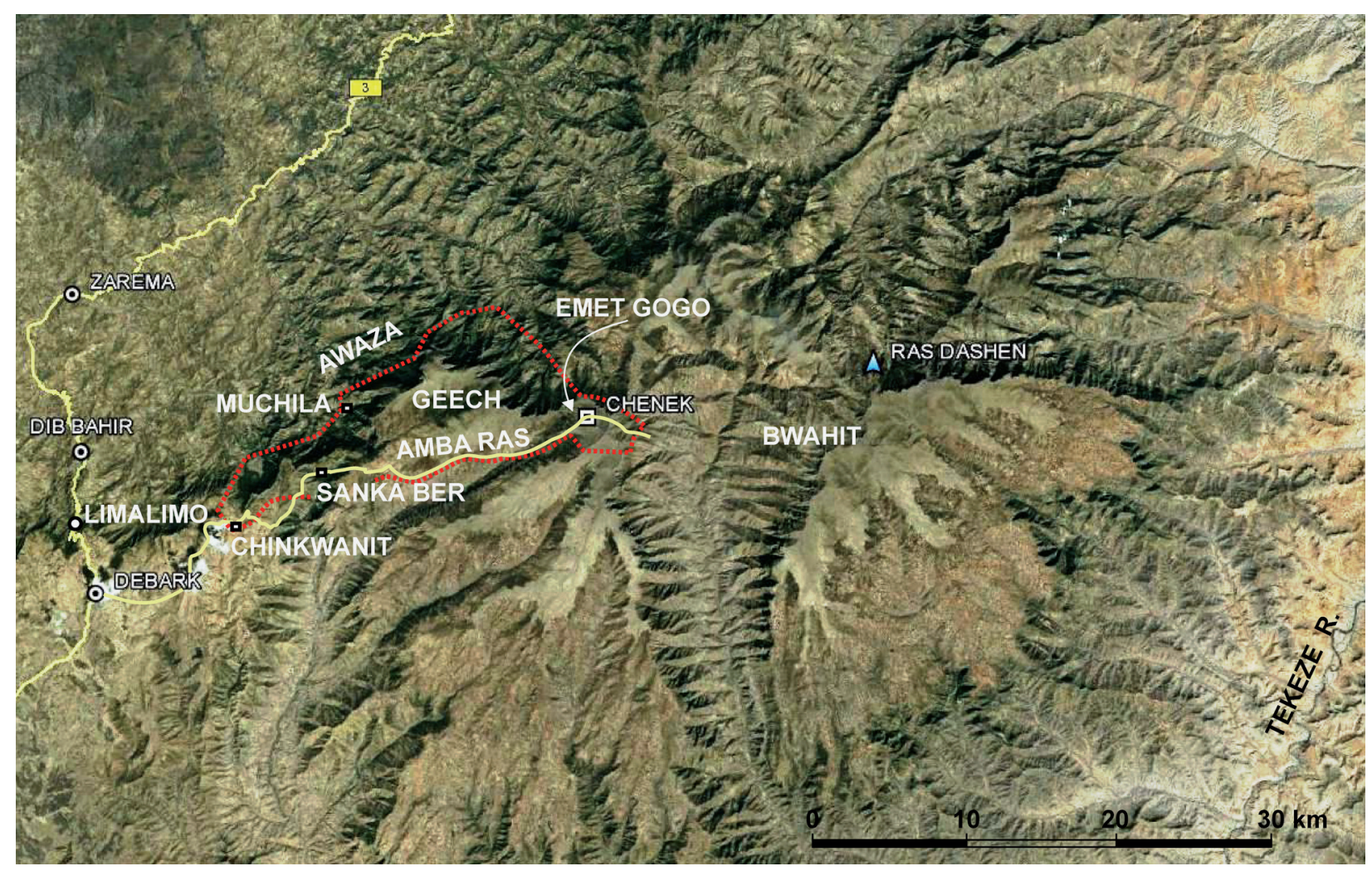

Fig. 5. Satellite imagery of the Simien Shield showing the landmarks mentioned in the text. The dotted red line marks the approximate boundary of the Simien Mountains National Park. 
columnar-jointed basalt flow overlain by $\sim 200 \mathrm{~m}$ thick rhyolitic tuffs and ignimbrites at the bottom, and intercalations of sparsely porphyritic, 10-15 $\mathrm{m}$ thick, massive lava flows and thin beds of columnar-jointed obsidians and tuffs, at the top. Thin beds of scoriaceous basalts and numerous palaeosols are also commonly exposed interspersed within the lava flows.

The contact between the upper flood basalt formation and the shield volcano is exposed at an altitude of $\sim 2,700 \mathrm{~m}$, and dips about $5^{\circ}$ away from the summit of the shield. Similar dips $\left(3-4^{\circ}\right)$ were earlier reported for the same contact at an altitude of 2,700 m (Kieffer et al. 2004). The shield volcanic sequences form slightly dipping (about $5^{\circ}$ ), thin (up to $3 \mathrm{~m}$ thick), discontinuous beds of slightly to highly porphritic basalts at the bottom, highly propyritic trachybasalt flows in the middle, and more heterogeneous intercalations of columnar-jointed slightly porphyritic basalt, highly porphyritic trachybasalt, trachytic and rhyolitic tuff, as well as columnar-jointed, slightly porphyritic alkali basalt, at the top. Due to the dipping away from the summit, the lower shield unit (dominantly porphyritic basalt) is exposed all the way up to altitudes of more than $4,000 \mathrm{~m}$. The middle (dominantly trachybasalts) and the upper heterogeneous sequences are mostly exposed at middle altitudes (around 2,800-3,000 m). The geomorphological setup suggests that these two units must have been removed from the upper levels due to continuous erosion which resulted in the current rugged topography of the Simien Shield. Quaternary wet-dry cycles (glaciations and deglaciation as well as rainfall-driven erosion) must have also played some role in sculpting the final morphology of the highest reaches of the Mountains.

\subsection{Geosceneries and geosites}

The Simien Mountains are accessed from the north along the Shire-Gondar road which winds along the western scarps of the Mountains starting at the lower reaches at the town of Zarema, through the scenic scarps and precipices of the Lima Limo pass towards the town of Debark located at the plateau. This road exposes most of the flood basalt sequence and the lower levels of the shield volcano. A road that starts from Debark and transects the National Park from west to east gives access to the major part of the shield volcano. The geoscenic views along these two roads are described below.

\subsubsection{Geosceneries and geosites along Zarema-Debark road}

Zarema is a small town located at a narrow river valley formed by the west flowing Zarema River, which starts at the western scarps of the Simien Mountains. The main road transects the town at an elevation of $1,240 \mathrm{~m}$ a.s.l. and winds up the mountains for about $1,640 \mathrm{~m}$ to reach at the town of Debark located at an elevation of 2,880 $\mathrm{m}$ a.s.1., $38 \mathrm{~km}$ away. The road follows a flat valley bottom for about $10 \mathrm{~km}$ before it starts to climb up the cliffs of the escarpments from 1,200 $\mathrm{m}$ a.s.l. to about $2,200 \mathrm{~m}$ a.s.l. in a $12 \mathrm{~km}$ stretch. At Dib Bahir, about $22 \mathrm{~km}$ from Zarema, the Lima Limo pass starts to wind up the highest reaches of the western escarpment for about $12 \mathrm{~km}$ before it reaches the plateau at about 2,800 m elevation.

The view from Zarema towards the east and southeast is spectacular with the eroded mountain peaks and occasional volcanic plugs forming spires over horizontally to sub-horizontally bedded volcanic sequences. These eroded volcanic sequences form the lower reaches of the Simien Mountains and form series of summits truncated by intersecting deep valleys and gorges (Fig. 6) generally running in the northeast-southwest and northwest-southeast directions.

A closer view of these eroded scarps and valleys shows horizontally to sub-horizontally bedded trap basalt sequences, which individually are a few meters thick, and as a whole forming

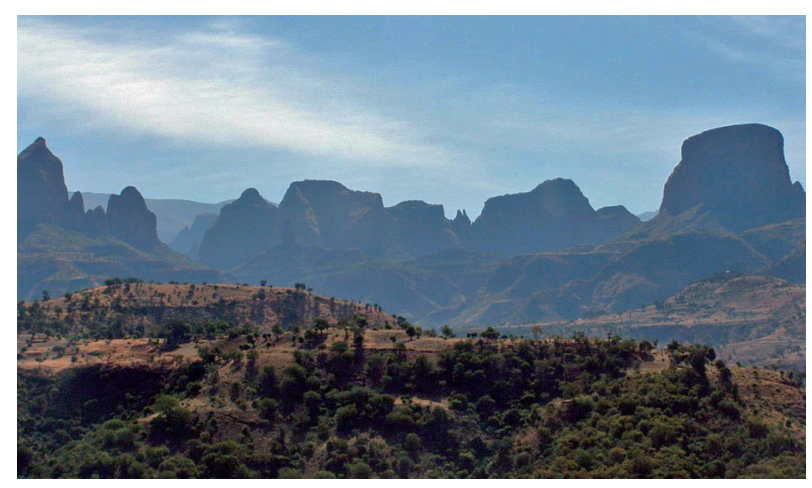

Fig. 6. Spires and peaks of eroded volcanic sequences truncated by deep gorges (view towards the east from Zarema). 


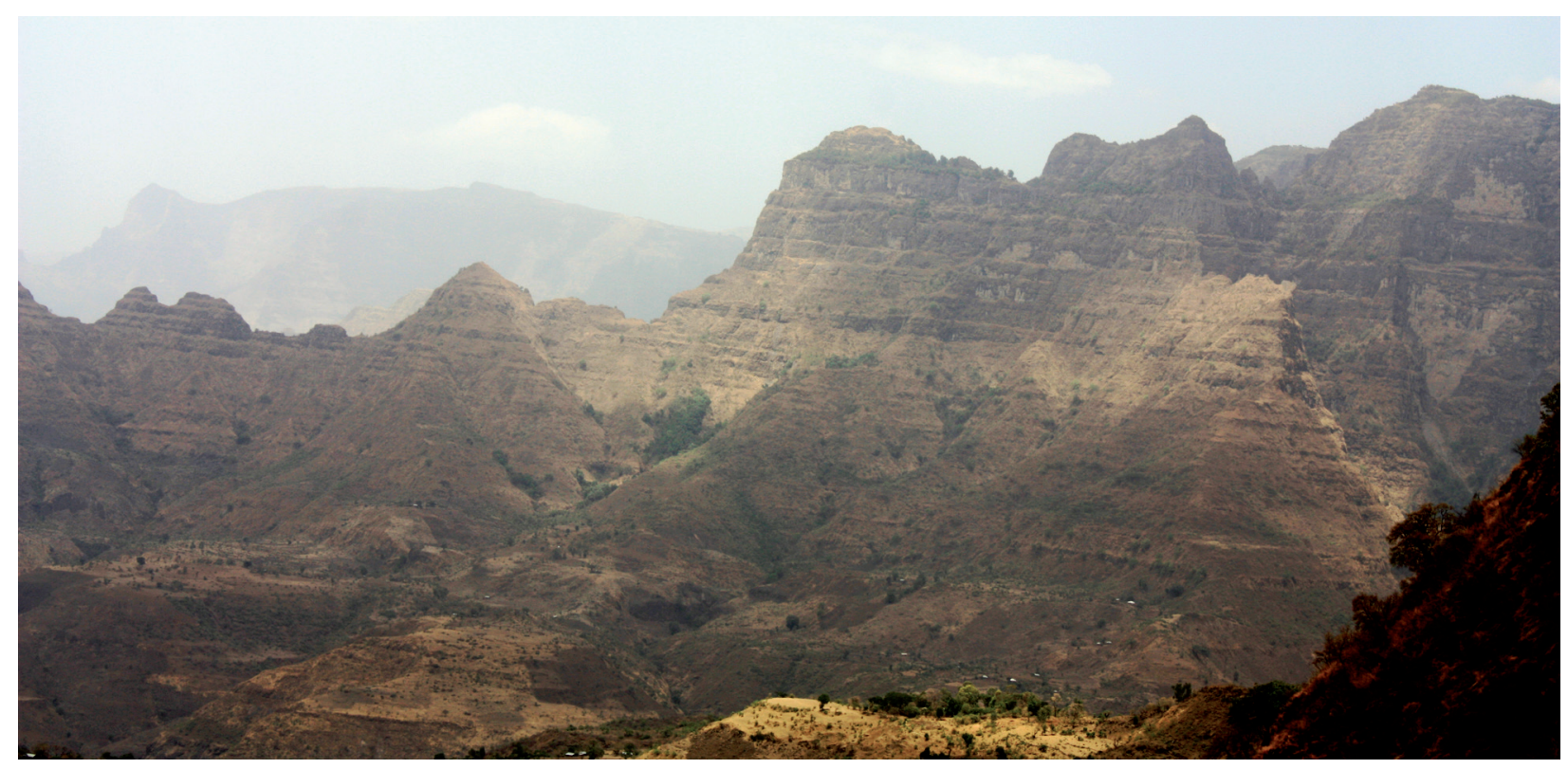

Fig. 7. Closer view of the cliffs shows individual layers within the flood basalt sequence.

prominent cliffs with thicknesses reaching a few hundred meters each. The valley bottoms and the saddles of the cliffs are generally inhabited and intensively cultivated. A continuous interplay of natural erosion and man-made activities resulted in complete exposure of the volcanic sequences to the extent that individual layers could be easily discerned from a distance of tens of kilometres (Fig. 7).

The Lima Limo pass is a very famous stretch of highland road because of the monumental cliff walls above, and very deep and narrow ravines below the road, which follows the major scarp at the western margin of the Simien Mountains. Individual cliffs form nearly vertical walls of a couple of hundred meters height. From the Lima Limo pass, the western lowlands adjoining the Simien Mountains can be observed.

\subsubsection{Geosceneries and geosites along the Debark-Chenek camp}

Debark, a bustling small town of nearly 30,000 inhabitants located about $100 \mathrm{~km}$ north of Gondar, is the closest town to the Simien Mountains National Park and the seat of the headquarters of the park. Located within a small depression at the top of a plateau, it is at the crossroads between the Simien shield to the east, the western lowlands to the west and northwest and the North-western Ethiopian plateau to the south. The road that transects the park starts from Debark at an eleva- tion of 2,880 $\mathrm{m}$ and climbs up to the foot of the highest peaks in the shield at altitudes of more than 4,000 $\mathrm{m}$ a.s.l., along a narrow highland strip oriented in a north-easterly direction with adjoining lowlands and ravines to the north and south. The road follows a very scenic strip often times winding above, and close to vertical precipices of more than $1 \mathrm{~km}$ throws (Fig. 8). Combined tectonic and erosive forces led to deep cutting down the beds of volcanic layers forming nearly isolated landmasses surrounded by vertical precipices and joined to the main highland strip by narrow land bridges wide enough to support only narrow foot paths. These nearly isolated landmasses are great refuges of the numerous fauna and flora, as well as religious sanctuaries, common in the Simien Mountains.

Driving along the road to Chenek, the eastern most campsite in the Simien Mountains National Park, presents spectacular views at various vintage points both outside and within the national park. The view from the road towards the north presents a series of majestic highland ridges aligned in a general east-west direction. These ridges and adjoining valleys are results of uplifting accompanied by deep incision, which eventually formed the river systems flowing to the west and feed the Tekeze River in the western lowlands. The lowest reaches of the ridges are similarly affected by erosional processes resulting in a beautiful mosaic of peaks and val- 


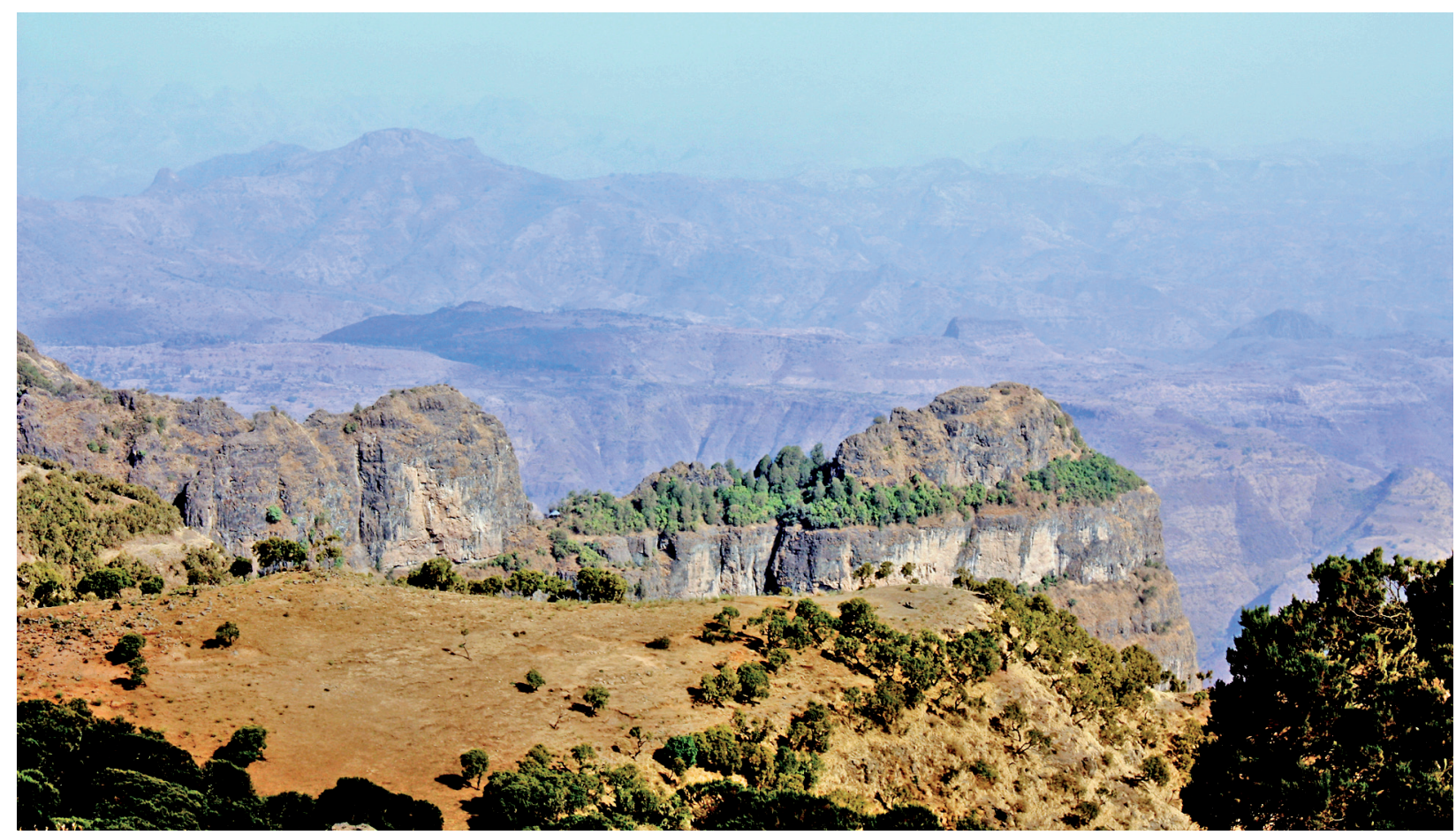

Fig. 8. The road oftentimes is a few meters away from the top of the escarpment and gives access to nearly isolated highland blocks (middle of photograph) by a narrow foot path (view towards northeast).

leys (Fig. 9) with interlinking river systems, occupying a broad area in the northern extremities of the Simien massif. The landmark view of the Simien Mountains, which are series of nestled prominent landmasses known as the Awaza peaks (Fig. 10), form part of the northern most ridges of the Simien massif. These peaks are remnants of a deeply eroded ridge which forms the most distant fringes of the pyroclastic flows associated with the shield volcanism.

The western most vintage point is the Chinkwanit pass, which is the place where the main road is a few meters away from the top of a precipice more than 1,000 $\mathrm{m}$ below. A succession of both

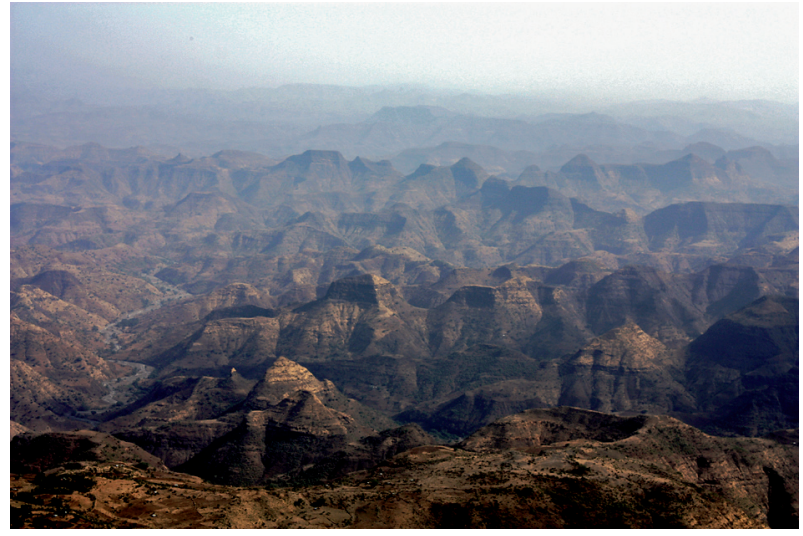

Fig. 9. An erosive landform at the lower reaches of the Simien Massif forming a mosaic of peaks and valleys (view towards the north).

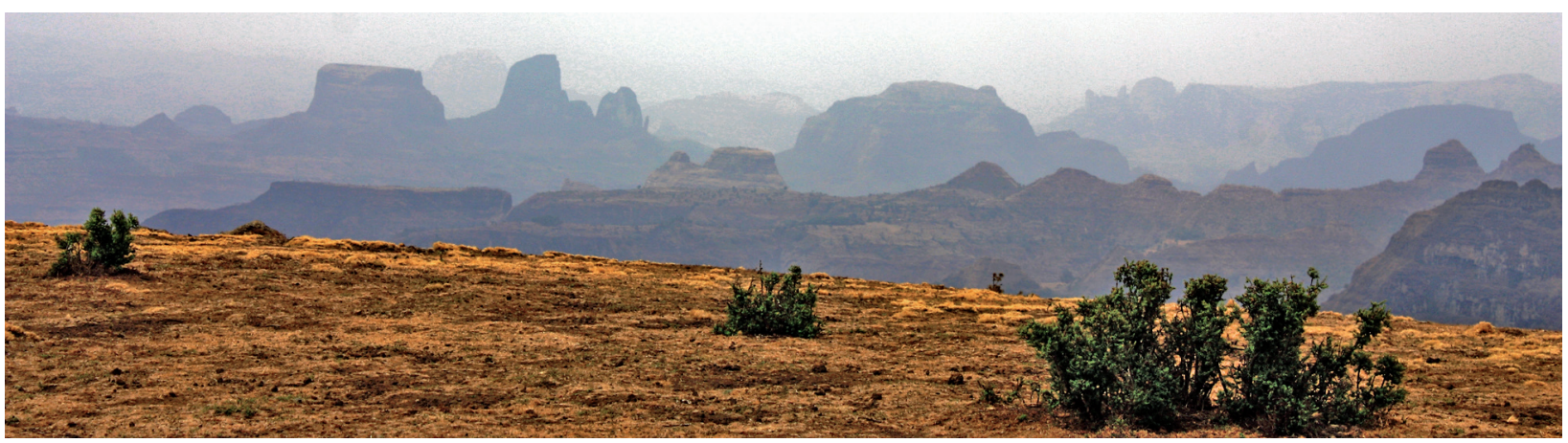

Fig. 10. View towards north from the road opens to the landmark view of the Simien Mountains. The Awaza peaks, in the middle background, are remnants of deep erosion of the northern most fringes of the shield volcanic sequence. 


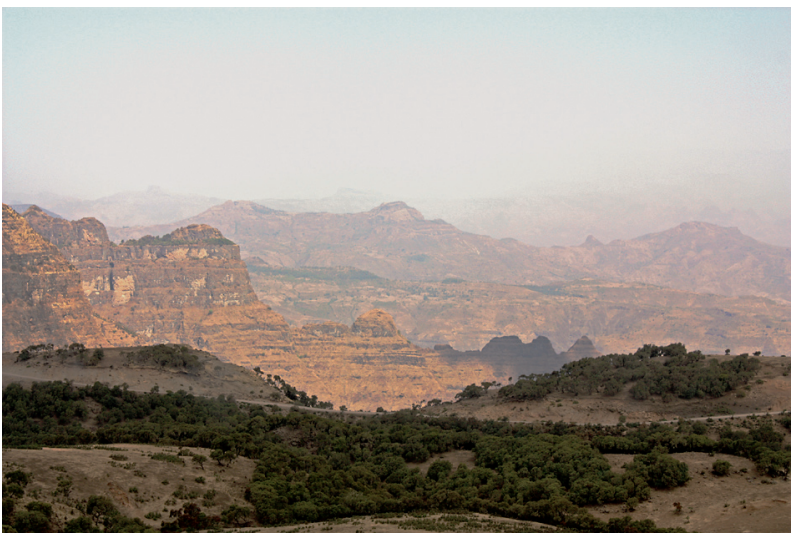

Fig. 11. The Sanka Ber campsite (foreground) is located at a narrow land bridge joining the western and eastern plateaus. Vertical walls to the north (background) expose a thick sequence of both shield volcanic and flood basalts.

shield volcanic materials and the topmost part of the flood basalt sequence is exposed at this precipice. The shield volcanic materials (intercalations of porphyritic basalts with trachytic and rhyolitic tuffs) can be easily observed at this section forming the upper part of the precipice, underlain by the upper flood basalt formation (porphyritic basalt flow), forming a saddle like contact which is marked by thickly wooded gorges.
The road from this vintage point winds up to a relatively wider summit. The road then crosses the ridge along a gently descending path until it reaches the Sanka Ber campsite. The drive along this ridge presents a view of the eastern and south-eastern flanks of the Simien shield, which generally show a slight dipping away from the point of observation, consistent with the fact that the centre of the shield lies towards the south. Sanka Ber campsite is located at a narrow land bridge only about $0.5 \mathrm{~km}$ wide. The land bridge connects two ridges, which in fact are the western and eastern parts of the national park. To the north and south of this land bridge are very deep ravines and gorges more than 1,500 $\mathrm{m}$ deep bordered by vertical walls and precipices (Fig. 11). These vertical precipices and ravines present a spectacular view and some of them boast narrow but long waterfalls during the rainy season. These vertical walls also present a great potential for rock climbing. These sections expose the lower part of the shield volcanic and the upper flood basalt formation and a closer look of the succession shows an intercalation of porphyritic olivine basalts and trachybasalts. From Sanka Ber camp-
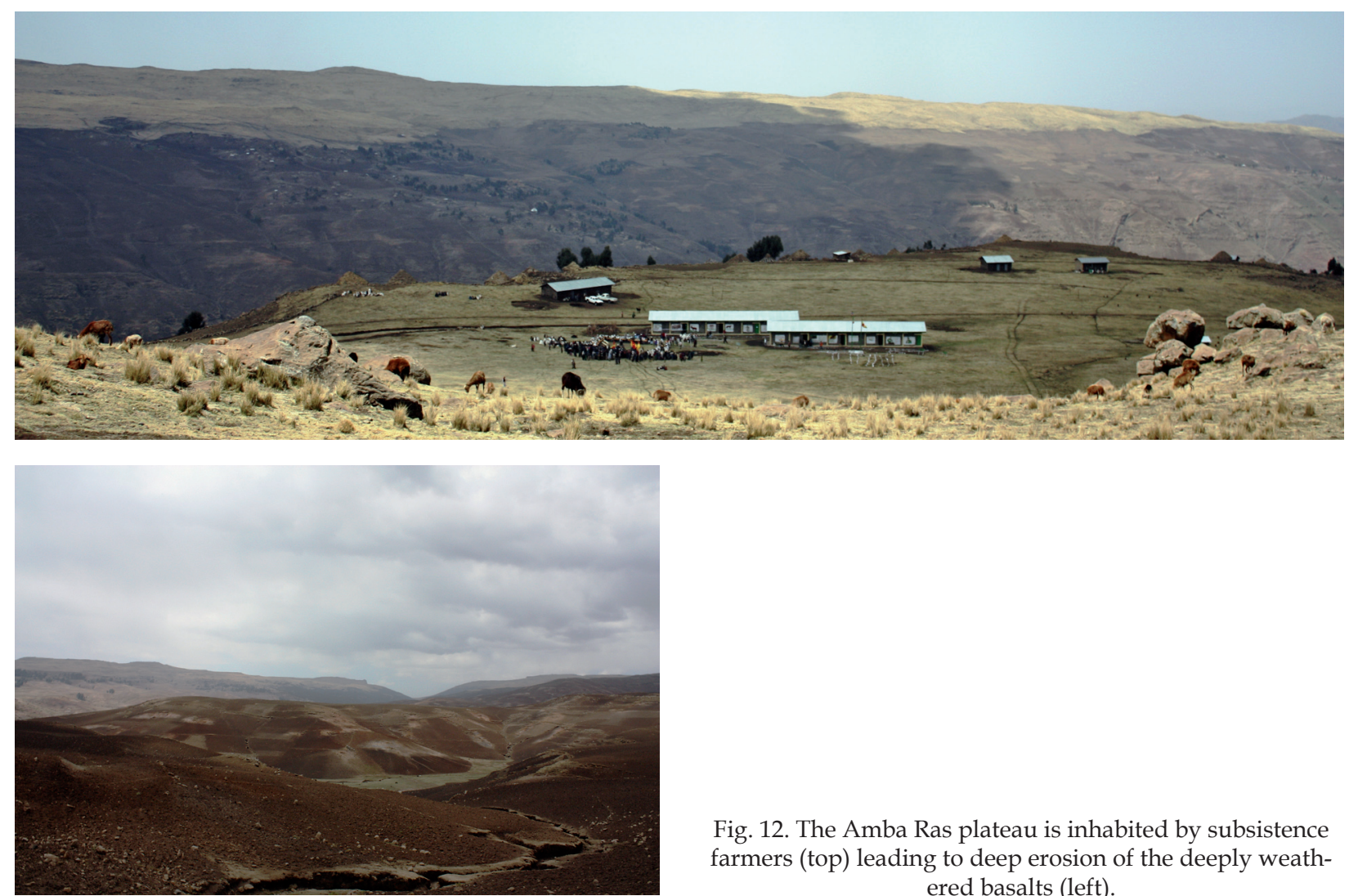

Fig. 12. The Amba Ras plateau is inhabited by subsistence farmers (top) leading to deep erosion of the deeply weathered basalts (left). 


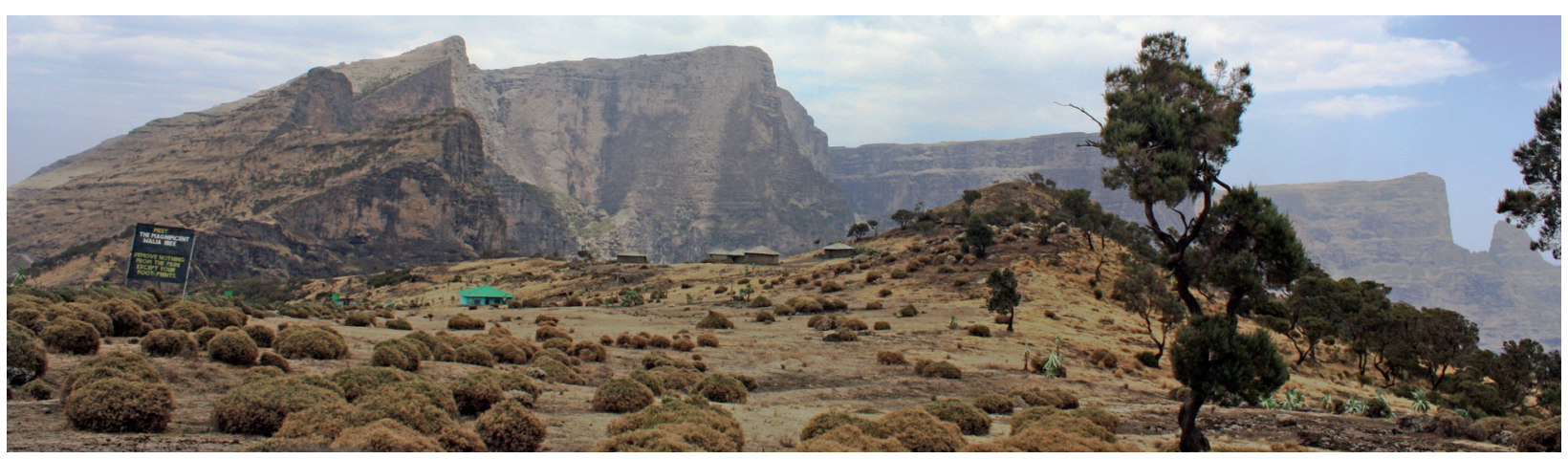

Fig. 13. The Chenek campsite (top), margins of the Amba Ras plateau and the Emet Gogo peak are in the background.

Views to the north from the Chenek campsite opening to the rugged terrain below (right).

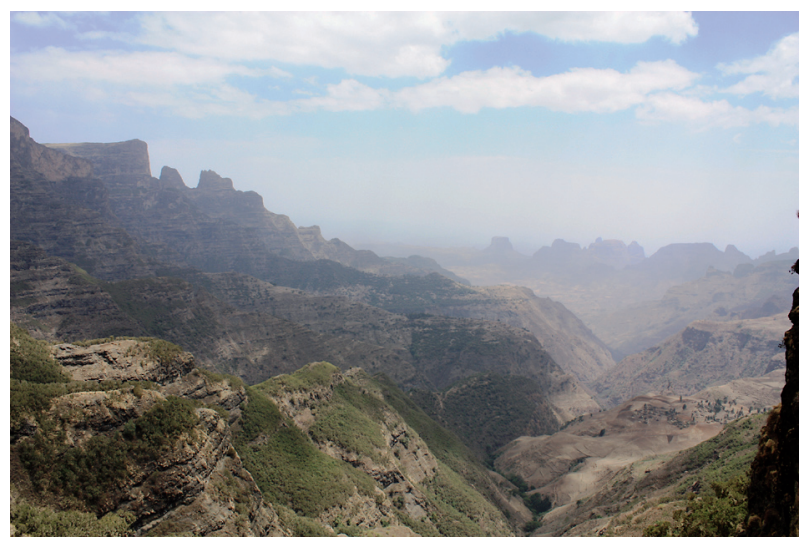

site, the Geech abyss to the east and the Muchila campsite to the northeast can be easily observed in a clear sky. The Geech abyss, located about

$1.5 \mathrm{~km}$ below the Sanka Ber campsite presents a frightening but owe inspiring view.
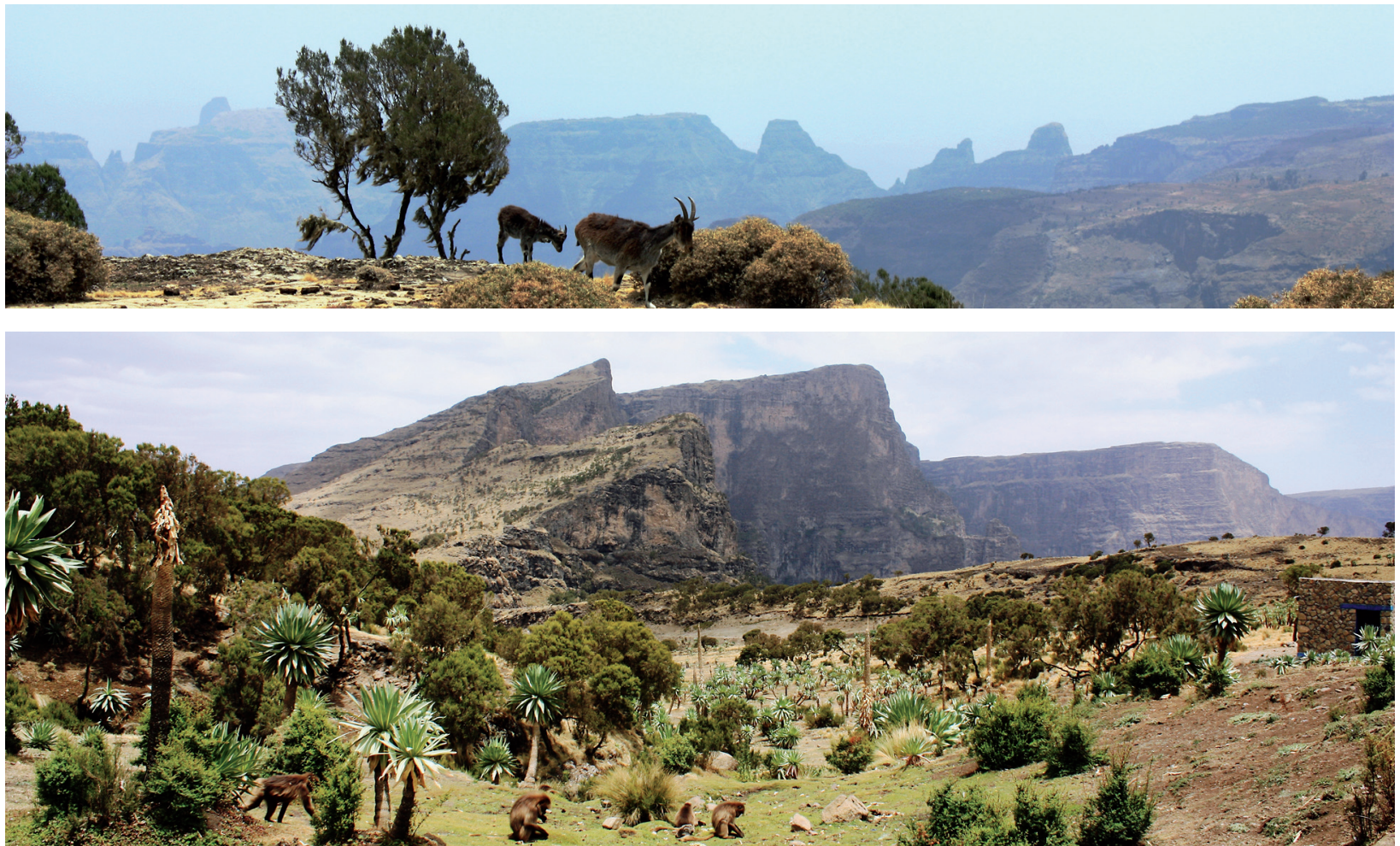

Fig. 14. The Chenek pass is a beautiful setting for its biodiversity: Top: Walia Ibex; Bottom: Gelada Baboon, giant lobelia as well as other highland flora surrounded by highland peaks and precipices (geodiversity). 
From Sanka Ber campsite the road winds up again to the Amba Ras plateau, which is about 8 $\mathrm{km}$ wide ridge, gently rising up towards the east from an elevation of about 3,000 $\mathrm{m}$ up to $3,500 \mathrm{~m}$ a.s.l. until the Chenek campsite. The Amba Ras plateau is generally affected by human encroachment manifested by the villages dotted within and close to the park boundaries and intense cultivation of the plateau (Fig. 12). The Amba Ras village (Fig. 12, top) located at an elevation of 3,200 m a.s.l. at the southern edge of the Amba Ras plateau and many other small villages are inhabited by subsistence farmers cultivating the strongly weathered and eroded plateau surfaces (Fig. 12, bottom).

The Chenek campsite (Fig. 13) is the most spectacular of all the vintage points within the park. Located at about 3,500 $\mathrm{m}$ a s. 1 . at the eastern margin of the Amba Ras plateau and at the foot of the Bwahit plateau to the south which rises to more than $4,400 \mathrm{~m}$ a.s.l., it is bounded to the north by a vertical precipice of more than $1,000 \mathrm{~m}$ depth, and opens to the northern rugged terrain. The vertical section below and above the Chenek campsite exposes the shield volcanic series of basalts, trachybasalts, rhyolites and tuffs. The Chenek campsite is surrounded by prominent peaks to the north and west and one of the most spectacular views is the Emet Gogo peak to the west which is a vertical edifice exposing horizontally layered volcanic sequences. A single cliff wall reaches more than $100 \mathrm{~m}$. The deep cutting and erosion resulted in curiously shaped spires and crags resembling high-rise buildings when viewed from distance.

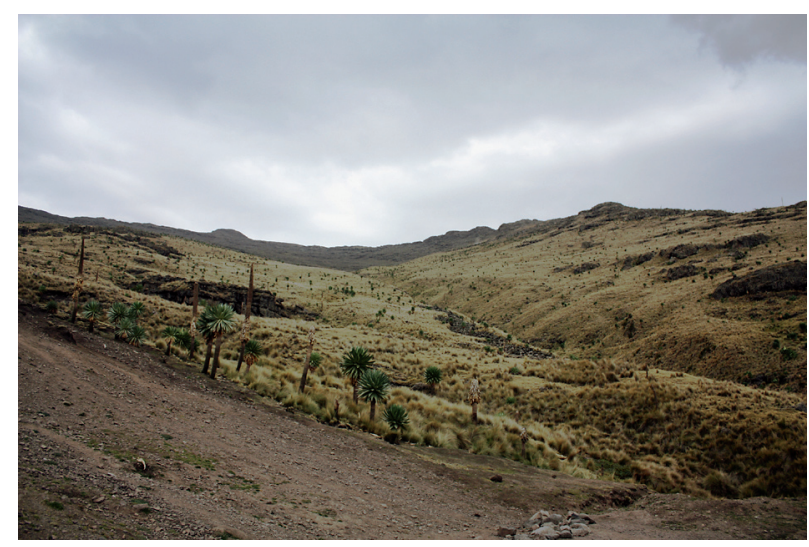

Fig. 15. Foot of the Bwahit plateau; the ridge in the foreground shows glaciated features (moraine).
The Chenek campsite is also famous for the trademark fauna and flora of the Simien Mountains. Walia Ibex, Gelada Baboon as well as the giant lobelia are observed at this site in abundance (Fig. 14). The small caves and saddles at the cliff faces of the basalt sequence are home to both the Walia Ibex and the Gelada Baboon, though both are commonly observed at the plateau surfaces during the day. From Chenek the road turns towards south and climbs up the Bwahit plateau, which is mostly underlain by rhyolitic flows and trachybasalts with some glaciated features (moraines; Fig. 15).

\section{Conclusions: proposed geoconservation sites}

The Simien Mountains fulfil all the criteria set for a geoheritage. In fact the Simien Mountains National Park can be considered as a geoheritage site, as the Park is equally important for its natural sceneries (geodiversities) and biodiversities (faunal and floral abundance). The Park's status as a World Heritage Site in the natural heritage category also supports this fact. However, the Simien Mountains have been throughout promoted for their biodiversity and little attention has been given to the geodiversity. The interference of human activities affects both the biodiversities and the geodiversities in the Simien Mountains. The above-described geodiversities have to be conserved for future generations, as they are the natural homes for the diverse flora and fauna for which the National Park is mostly known.

Though the vast territory of the Simien Mountains as a whole can be considered as geoheritage territory and we strongly suggest their conservation; for practical reasons, we propose the following particular sites to be considered as geoconservation sites: the Lima Limo pass, the Chinkwanit pass, the Awaza peaks, the Sanka Ber land bridge, the Chenek pass, the Geech Abyss, the Emet Gogo peak, and the Bwahit plateau.

\section{References}

Asrat A., 2002. The Rock-hewn churches of Tigrai, Northern Ethiopia: A geological perspective. Geoarchaeology, 17(7): 649-663. 
Asrat A., Barbey P., Gleizes G., 2001. The Precambrian Geology of Ethiopia: A review. Africa Geosciences Review, 8: 271-288.

Asrat A., Barbey P., Gleizes G., 2003. Magma emplacement and mafic-felsic magma hybridization: structural evidence from the Pan-African Negash pluton, Northern Ethiopia. Journal of Structural Geology, 25(9): 1451-1469.

Asrat A., Demissie M., Mogessie A., 2009. Geotourism in Ethiopia. Shama Books, Addis Ababa, Ethiopia.

Ayalew D., Marty B., YiRGU G., PIK R., 1999. Geochemical and Isotopic $(\mathrm{Sr}, \mathrm{Nd}$ and $\mathrm{Pb}$ ) characteristics of volcanic rocks from southwestern Ethiopia. Journal of African Earth Sciences, 29: 381-391.

Beyene A.M. \& Abdelsalam M.G., 2005. Tectonics of the Afar Depression: A review and synthesis. Journal of African Earth Sciences 41: 41-59.

Bosellini A., Russo A., Fantozzi P.L., Assefa G. \& Tadesse S., 1997. The Mesozoic succession of the Mekele Outlier (Tigrai Province, Ethiopia). Memorie di Scienze Geologiche, 49: 95- 116.

BROCX M., 2008. Geoheritage: from global perspective to local principles for conservation and planning. Western Australian Museum, Perth, Western Australia.

Brocx M. \& Semeniuk V., 2007. Geoheritage and Geoconservation-history, definition, scope and scale. Journal of the Royal Society of Western Australia, 90: 53-87.

Debonnet G., Melamari L. \& Bomhard B., 2006. Reactive Monitoring Mission to Simien Mountains National Park, Ethiopia. WHC/IUCN Mission Report, UNESCO, Paris \& IUCN, Switzerland.

Di PaOla G.M., 1972. The Ethiopian Rift valley (between $7^{\circ} 00^{\prime}$ and $8^{\circ} 40^{\prime} \mathrm{N}$ latitude). Bulletin Vulcanology, 36: 517-560.

Doyle P., Eastbrook G., Reid E., Skipsey E. \& Wilson C., 1994. Earth Heritage Conservation, Wilson C. (ed.), City Print Ltd., Milton Keynes, United Kingdom.

FishPoOL L. \& Evans M. (eds.), 2001. Important Bird Areas in Africa and Associated islands. Priority Sites for Conservation. Pisces, Newbury/Bird Life International, Cambridge U.K.

HAyward N. \& Ebinger C., 1996. Variations in the along-axis segmentation of the Afar rift system. Tectonics, 15(2): 244-257.

Hofmann C., Courtillot V., Feraud G., Rochette P., Yirgu G., Ketefo E. \& PIK R., 1997. Timing of the Ethiopian flood basalt event and implications for plume birth and global change. Nature, 389: 338-341.

Hurni H., 1986. Management Plan: Simien Mountains National Park and Surrounding Rural Area. UNESCO World Heritage Committee and Wildlife Conservation Organization, Ministry of Agriculture, Ethiopia.

Hurni H., 1995. Simien Mountains Baseline Study, Ethiopia. Intermediate report on the 1994 Field Expedition (Phase I). Ministry of Natural Resources, Development and Environmental Protection, Addis Ababa, Ethiopia.

Kieffer B., Arndt N., Lapierreet H., Bastien F., Bosch D., Pecher A., Yirgu G., Ayalew D., Weis D., Jerram D.A., Keller
F. \& Meugniot C., 2004. Flood and shield basalts from Ethiopia: magmas from the African superswell. Journal of Petrology, 45(4): 793-834.

Le Turdu, C. Tiercelin J.J., Gilbert E., Travi Y., Lezzar K., Richert J., Massault M., Gasse F., Bonnefille R., Decobert M., Gensous B., Jeudy V., Tamirat E., Mohammed M.U., Martens K., Balemwal A., Chernet T., Williamson D. \& Tатев M., 1999. The Ziway-Shalla Lake basin system, Main Ethiopian Rift: influence of volcanism, tectonics and climatic forcing on basin formation and sedimentation. Palaeogeography. Palaeoclimatology and Palaeoecology 150: 135-177.

MoHr P.A., 1962. The Ethiopian Rift System. Bulletin of the Geophysical Observatory of Addis Ababa, 5: 33-62.

Moнr P.A., 1967. Review of the geology of the Simien Mountains. Bulletin of the Geophysical Observatory of Addis Ababa, 10: 79-93.

Moнr P.A., 1983. Ethiopian flood basalt province. Nature 303 : 577-584.

Mohr P.A. \& Zanettin B., 1988. The Ethiopian flood basalt province. In: Macdougall J.D. (ed.), Continental Flood Basalts, Kluwer Academic, Dordrecht.

Pik R., Deniel C., Coulon C., Yirgu G., Hoffmann C. \& AyALEW D., 1998. The northwestern Ethiopian plateau flood basalts: classification and spatial distribution of magma types. Journal of Volcanology and Geothermal Research, 81: 91-111.

Pik R., Deniel C., Coulon C., Yirgu G., Martin B., 1999. Isotopic and trace element signatures of Ethiopian basalts: evidence for plume-lithosphere interactions. Geochimica and Cosmochimica Acta, 63: 2263-2279.

Pizzi A., Coltorti M., Aвebe B., Disperati L., Sacchi G. \& SalvINI R., 2006. The Wonji fault belt (Main Ethiopian Rift): Structural and geomorphological constraints and GPS monitoring. In: Yirgu G., Ebinger C.J., Maguire P.K.M. (eds.), The Afar Volcanic Province within the East African Rift System. Geological Society, London, Special Publications 259: 191-207.

SEMENUIK V., 1997. The linkage between biodiversity and geodiversity. In: Eberhard R. (ed.), Pattern and Process. Australia Environment Task Force, Canberra, Australia.

Semeniuk V. \& Semeniuk C.A., 2001. Human impacts on geoheritage features of the Swan Coastal plain and coastal zone Southwestern Australia. In: Gostin V.A. (ed.), Gondwana to Greenhouse: Australian Environmental Geosciences, Geological Society of Australia Inc., Sydney.

WHC, 2010. Simien National Park, Ethiopia. World Conservation Monitoring Center.

Wolfenden E., Ebinger C., Yirgu G., Renne P.R. \& Kelley S.P., 2005. Evolution of a volcanic rifted margin: Southern Red Sea, Ethiopia. Geol. Soc. Am. Bull., 117(7-8): 846-864.

Wright T.J., Ebinger C. Biggs J., Ayele A., Yirgu G., Keir D. \& STORK A., 2006. Magma-maintained rift segmentation at continental rupture in the 2005 Afar dyking episode. Nature, 442: 291-294. 